Assiut Scientific Nursing Journal

http://asnj.journals.ekb.eg

http://www.arabimpactfactor.com

\title{
Effect of Counseling about Vitamin D Deficiency Among Pregnant Women in Abo-teg Health Center
}

\author{
Reda Saad Hashem ${ }^{1}$, Hamida Almeldine Abed Elhafez ${ }^{2} \&$ Reda Refae Ali Abed Elwahed $^{3}$. \\ ${ }^{1 .}$ Teacher of Nursing at Technical Secondary School of Nursing in Abo-teg. \\ 2. Assistant Professor of Maternal \& Newborn Health Nursing department, Faculty of Nursing, Assuit University. \\ ${ }^{3 .}$ Lecturer of Maternal \& Newborn Health Nursing department, Faculty of Nursing, Assuit University
}

\begin{abstract}
Background: Counseling is a short term process helps to bring change in life, change in thought, and change in behavior. Vitamin D deficiency is present in high percentage in pregnant women and caused adverse maternal and fetal complications as gestational diabetes, preeclampsia, low birth weight and preterm labor. The aim of this study was to evaluate the effect of counseling about vitamin D deficiency on pregnant women in Ab-teg Health Center. Samples: A convenient sample of 400 pregnant women. Research design: a quasi - experimental design was applied in this study. Setting: The study was conducted in six places of maternal and child health centers of Abo-teg city and it's villages. Tools: Structured interviewing questionnaire were utilized for data collection and pre-post counseling questionnaire to evaluated the effect of counseling on vitamin D. Results: Most of participated women in this study under 30 years, there were a statistically significant increase in studied women general knowledge about vitamin ( $\mathrm{p}<0.01)$ after counseling. Conclusion: Counseling on vitamin D deficiency is effective and pregnant women`s knowledge towards vitamin D deficiency and its effect on pregnancy outcomes become adequate. Recommendations: The study recommended conducting awareness sessions on vitamin D and its importance for the expectant mothers and their children to improve pregnancy outcomes.
\end{abstract}

\section{Keywords: Counseling, Pregnant Women \& Vitamin D Deficiency.}

\section{Introduction}

Vitamin D is a fat-soluble vitamin that is naturally present in very few foods, and available as a dietary supplement. When ultraviolet rays from sunlight strike the skin vitamin D is synthesized (NIH, 2020). Its known that vitamin D play an important role in bone metabolism through regulation of calcium and phosphate equilibrium. During exposure to sunlight vitamin $\mathrm{D}$ is produced by the body, but is also found in oily fish, eggs and fortified food products (WHO, 2019).

Vitamin D is called the "sunshine vitamin" because the skin produced it in response to sunlight. It's one of a fat-soluble vitamin family that includes vitamins D-1, D-2, and D-3. Vitamin D produces naturally when the skin directly exposed to sunlight. Also get it through certain foods and supplements to ensure adequate levels of the vitamin in blood (Debra, 2020) Vitamin D has two major types, Vitamin D2 "ergocalciferol" which is synthesized by plants and is not produced by the human body, Vitamin D3 "cholecalciferol" which is made in large quantities in the skin when sunlight strikes bare skin. It can also be ingested from animal sources (Siemens Healthineers, 2019)

Vitamin D help the body to absorb calcium (one of bone's main building blocks) from food and supplements. A condition known as rickets in children and osteomalacia in adult may present in people who get too little vitamin D and develop soft, thin, and brittle bones, Muscles need vitamin D to move, nerves also need it to carry messages between every body part and the brain, and the immune system needs it to fight off invading bacteria and viruses. Vitamin D also helps protect older adults from osteoporosis (NIH, 2016).

Vitamin D deficiency is reported to be as high as $40 \%$ among pregnant women and is also very common and profound during lactation. The requirements of vitamin $\mathrm{D}$ increase during pregnancy progresses, a compromised maternal vitamin D status has been associated with an approximately two-fold increased prevalence of congenital heart defects in off springs and a higher incidence of fetal miscarriage, gestational diabetes, bacterial vaginosis and perinatal depression in mothers, other than impaired fetal and childhood growth (Fogacci et al., 2019).

Vitamin D deficiency and inadequacy are very common during pregnancy, and their incidence can reach up to $96.0 \%$ to $99.4 \%$. Vitamin D deficiency in pregnant women is associated with various adverse pregnancy outcomes in the mother (preeclampsia, gestational diabetes, cesarean section, and infectious disease), fetus (gestational duration), and offspring (type 1 diabetes, eczema, and inflammatory and atopic disorders) (Hong-Bi, 2018). 
Vitamin D has become increasingly recognized as a pluripotent regulator of biological functions above and beyond its classical effects on bone and calcium homeostasis. One of the first extra-renal tissues shown to be capable of synthesizing $1,25(\mathrm{OH}) 2 \mathrm{D}$ is the placenta, with CYP27B1 activity detectable in both maternal decidua and fetal trophoblast, this was linked to the rise in maternal serum $1,25(\mathrm{OH}) 2 \mathrm{D}$ that occurs at the end of the first trimester of pregnancy (Ganguly et al., 2018).

Vitamin D deficiency has been observed with high prevalence among pregnant women even in sun-rich areas Several studies reported the relationship between maternal vitamin D deficiency and adverse maternal and fetal outcomes including gestational diabetes, preeclampsia, preterm labor, low birth weight, and caesarean section (Ates et al., 2016).

\section{Significant of the study}

In Egypt, high prevalence of vitamin D deficiency among pregnant women and their neonates in the first week of life was recorded (47 to $86 \%$ ), There was a significant relation between serum vitamin D status of the mother and her newborn (Mohamed, 2018).

In Egypt, A study on vitamin D status in Egyptian females showed a high prevalence of vitamin D deficiency among healthy Egyptian females of different age groups, Vitamin D deficiency accounted for $72.6 \%$ of the lactating group, $54 \%$ of the pregnant group, $72 \%$ of the childbearing age group (Raif et al., 2015).

Vitamin D deficiency is identified as a global health problem and has affected more than 1 billion people globally, especially among pregnant women. The vitamin D deficiency and insufficiency prevalence during pregnancy ranges from $27 \%$ to $91 \%$ in the United States, $39 \%$ to $65 \%$ in Canada, $45 \%$ to $100 \%$ in Asia, $19 \%$ to $96 \%$ in Europe, and $25 \%$ to $87 \%$ in Australia (Woon, 2019).

\section{Aim of the study}

To evaluate the effect of counseling about vitamin D deficiency on pregnant women in Abo-teg Health Center.

\section{Research hypothesis}

Counseling on vitamin D deficiency among pregnant women will be effective and elevate pregnant women`s knowledge towards vitamin D deficiency and its effect on pregnancy outcomes.

\section{Patients \& Methods \\ Study design}

A quasi - experimental research design was applied to execute this study.

\section{Setting}

The study was conducted in six places of Ante-Natal Care clinics (ANC) and maternal and child health Centers $(\mathrm{MCH})$ of the city of Abo-teg and its villages that consist "Abo-teg, Banysemea, Alneghelaa, Alzarapy, Bakoor and Nazlet-Bakoor".

The health center in Abo-teg are divided into eastern and western centers of the Nile, the eastern centers are (Alneghelaa, Bakoor and Nazlet-Bakoor) and the western centers are (Alzarapy and Banysemea) and in the middle the Abo-teg health center, these six health centers are the most popular places that provide care and services for expectant mothers in the city of Aboteg as antenatal care, vaccinations for mothers and their children, family planning services, laboratory tests, premarital screening and health education.

Sample

A convenient sample was conducted in this study.

Sample Size formula: According to sample size equation the sample included $\mathbf{3 7 0}$ pregnant women. But 400 pregnant women were conducted in this study to avoid any statistical error.

About 9468 pregnant women attended to these six $\mathrm{MCH}$ that involved in this study in the year of 20182019. The number of pregnant women participating in this study in each health center is estimated as following (156 in Abo-teg, 80 in Alneghelaa, 53 in Alzarapy, 43 in Bakoor, 42 in Banysemea and 26 in Nazlet-Bakoor).

$$
\begin{gathered}
S s=\frac{Z^{2 * p *(1-p)}}{e^{2}} \\
S ~ s=\frac{1+\left[Z^{2 * p(1-p)]}\right.}{e^{2 * N}}
\end{gathered}
$$

Ss $=$ sample size

$\mathrm{Z}=$ Reliable levels is 0.95 and is equates to 1.96

$\mathrm{E}=$ The error ratio $=0.05$

$\mathrm{P}=$ The property available ratio and neutral $=0.5$

$\mathrm{N}=$ Total population size "total attended pregnant women to maternal and child health Centers of Aboteg city and it's villages during year 2018-2019".

$\mathrm{S} \quad \mathrm{S}=\left[(1.96)^{2} * 0.5 *(1-0.5)\right] /(0.05)^{2}=$ $[3.8416 * 0.5 * 0.5] / 0.0025=0.9604 / 0.0025=384.16$

Sample size $=\quad 384.16 / 1+[(384.16-$ 1) $/ 9468]=384.16 /(1+0.041)=369.03$ By overdrive the minimum required to this study is $\underline{370}$ pregnant women.

\section{Inclusion criteria}

All pregnant women between 20 and 36 weeks of gestation "prime \& multi", pregnant age from 18 to 49 years old, pregnant women who are eligible and willing to take part in the study and pregnant women who already have vitamin $\mathrm{D}$ deficiency.

Tools of data collection:

Two tools were utilized to collect data of the present study.

Tool 1: Structured interview questionnaire

It divided into four parts, it was utilized to collect data for this study and to assess socio-demographic data, medical history for any diseases and obstetric 
history "Current \& pervious". It was developed by the researcher after reviewing and utilizing the most recent and relevant literature.

Part 1: Socio-demographic data included name, age, residence, educational level, working status and phone number.

Part 2: Anthrometric measurement involved assessing the body weight in kilograms and height in centimeters to calculate the body mass index (BMI).

$\mathrm{BMI}={\underline{\text { Weight }}(\text { in } \mathrm{kg})^{2}}^{2}$

Height (in cm)

Part 3: Medical history for any diseases included diabetes mellitus, hypertension, renal disease, cardiac disease, hepatic disease, and any other diagnosed medical disease.

\section{Part 4: Obstetric history}

A] Current obstetrical history included gestational age, spacing from last delivery or abortion, any pregnancy complications as" preeclampsia, gestational diabetes, bacterial vaginosis in pregnancy".

B] pervious obstetrical history included gravidity, parity, history of preeclampsia, gestational diabetes mellitus, caesarean section, postpartum hemorrhage, abortion, pre mature rupture of membrane "PROM", preterm labor, bacterial vaginosis in pregnancy, low birth weight, premature birth, fetal intrauterine growth restriction, neonatal hypocalcaemia, childhood obesity and still birth.

Tool II: Pre-post counseling questionnaire for Women's Knowledge about vitamin D deficiency and its effect on pregnancy out comes:

It was developed to assess women's knowledge about vitamin $\mathrm{D}$ and its effect on pregnancy out comes included; what is vitamin $\mathrm{D}$, normal level of vitamin $\mathrm{D}$, sources of vitamin $\mathrm{D}$, signs and symptoms of vitamin D deficiency, effect of vitamin D deficiency on pregnancy outcomes, Can people get enough vitamin D through their diet, intake of vitamin D supplements and treatment of vitamin D deficiency.

\section{Knowledge scoring system}

Each question was scored as (1) for a correct answer and (zero) for an incorrect answer. While the total knowledge score was calculated as the following: knowledge was considered inadequate if the total score was less than $60 \%$ (less than 20 score) and was consider adequate if total score was $60 \%$ and more (20 score or more).

\section{Methods}

\section{Face validity and reliability}

Face validity was done by 3 experts from Maternal \& Newborn Health Nursing staff who reviewed the tools for clarity, relevance, and comprehensiveness. Modifications were done and correction was carried out accordingly and then the tools were designed in their final format and tested for reliability.
Pilot study

The pilot study carried out in December 2019 in order to test the feasibility and applicability of the tools. It was conducted on $10 \%$ of the sample (40 pregnant women). Conformation were done according to the pilot study. Those pregnant women who were involved in the pilot study were included in the study. Field work: The current study was carried out in three phases; preparatory phase, implementation phase and evaluation phase.

\section{Procedure}

Preparatory phase

- Obtained the permission to run out the study from the ethical committee of the faculty of Nursing.

- An official letter issued from the Dean of the Faculty of Nursing to the director of Ante-Natal Care (ANC) clinics \& $(\mathrm{MCH})$ of Abo-teg city "Assiut Governorate " after explaining the purpose of the study.

- The researcher emphasized that the participation was voluntary and the pregnant women had the right to refuse participation in the study and can withdraw at any time.

- Verbal consent was obtained from each pregnant women prior to her contribution in the study, also anonymity and confidentiality are assured through coding all of data.

\section{Implementation phase}

- The researcher greeted the pregnant women, introduced herself and explained the purpose of study to those agreed to participate in the study prior to any data collection.

- Each pregnant women involved in the study was interviewed individually "pre counseling questionnaire", conducted to collect data and assess (patient's name, age, residence, educational level, working status and phone number)

- Assessed body weight in $\mathrm{kg}$ and height in centimeter to calculate body mass index (BMI).

- Assessed medical history for any diseases included diabetes mellitus, hypertension, renal disease, cardiac disease, hepatic disease, and any other diagnosed medical disease.

- Current obstetrical history included gestational age, spacing from last delivery or abortion, any pregnancy complications as" preeclampsia, gestational diabetes, bacterial vaginosis in pregnancy".

- Pervious obstetrical history included gravidity, parity, history of preeclampsia, gestational diabetes mellitus, caesarean section, postpartum hemorrhage, low birth weight, pre mature rupture of membrane "PROM", preterm labor, and bacterial vaginosis in pregnancy.

- Assessed women's knowledge about vitamin D and its effect on pregnancy out comes included; 
what is vitamin $\mathrm{D}$, normal level of vitamin $\mathrm{D}$, sources of vitamin D, signs and symptoms of vitamin D deficiency, effect of vitamin D deficiency on pregnancy outcomes, Can people get enough vitamin D through their diet, intake of vitamin $\mathrm{D}$ supplements and treatment of vitamin D deficiency.

- This session took about 15-20 minutes.

\section{Counseling}

- The researcher explained in details all information about vitamin $\mathrm{D}$ and the effect of vitamin $\mathrm{D}$ deficiency on pregnancy outcomes. A brochure was given to each mother as a supportive material. It was developed and translated in a simple Arabic language by the researcher based on women's assessment needs, literature review, researcher experience and opinion of the nursing expertise, it included information on vitamin $\mathrm{D}$ as [what is vitamin $\mathrm{D}$, normal level, sources of vitamin $\mathrm{D}$, signs and symptoms of vitamin D deficiency, effect of vitamin D deficiency on pregnancy, risk factors \& treatment of vitamin D deficiency].

- Giving advice to the pregnant woman according her physical condition, educational level, financial status and her needs as "mother class".

- The researcher used pictures to enhance pregnant women's understanding and helped them to retain the learned information.

- This session took about 20-30 minutes.

- Each session included from 5 to 10 pregnant women two times per week.

\section{The evaluation phase Post-counseling questionnaire}

- It carried out after completion of the educational intervention, reassessment of women`s knowledge after counseling "post counseling questionnaire" once again to evaluated the effect of counseling on vitamin $\mathrm{D}$ deficiency and its effect on pregnancy out comes, and compare it with the pre intervention phase (sheet).

- Post counseling questionnaire done immediately after counseling.

- This session took about 15-20 minutes.

- The collection of data lasted (6) months through the period from first of December 2019 to end of March 2020, then from first of July to end of August, because low number of pregnant women who participating in the study with the presence of Covid-19 pandemic.

\section{Ethical considerations}

The Ethical Committee in the Faculty of Nursing has approved the proposed research, there was no risk for study subjects during application of research, the common ethical principles in clinical research has been followed in the study, oral consent was obtained from the pregnant women that were willing to participate in study, after explaining the nature and purpose the study, confidentiality and anonymity were assured. Subjects had the right to refuse to participate in the study and or withdraw from the study without any rational any time and study subjects privacy was considered during collection of data.

\section{Statistical analysis}

The collected data were organized, categorized, coded, tabulated and analyzed using the Statistical Package for social sciences (SPSS) version 18. Data were presented and tables and charts using numbers, percentages, means, standard deviation. Mc Nemar test used for pair qualitative variables, also chi-square test of significance was used in order to find an association between variables. Statistical significance difference was considered at $\mathrm{P}$-value $\leq 0.05$ and highly statistical significance was considered at Pvalue $\leq 0.01$. 


\section{Results}

Table (1): Distribution of studied women according to their Socio demographic characteristics $(n=400)$

\begin{tabular}{|c|c|c|}
\hline Socio demographic characteristics & n. (400) & $\%$ \\
\hline $\begin{aligned} \text { 1) Age/years: } \\
\text { - } 18-<25 \text { years } \\
\text { - } 26-<30 \text { years } \\
\text { - } 31-<35 \text { years } \\
\text { - }>35 \text { years }\end{aligned}$ & $\begin{array}{l}168 \\
136 \\
59 \\
37\end{array}$ & $\begin{array}{c}42.0 \\
34.0 \\
14.75 \\
9.25\end{array}$ \\
\hline Mean age & \multicolumn{2}{|c|}{$27.3 \pm 5.48$} \\
\hline $\begin{array}{l}\text { 2) Residence: } \\
\text { - Urban } \\
\text { - Rural }\end{array}$ & $\begin{array}{l}156 \\
244\end{array}$ & $\begin{array}{l}39.0 \\
61.0\end{array}$ \\
\hline $\begin{array}{l}\text { 3) Educational level: } \\
\text { - Illiterate } \\
\text { - Read and write } \\
\text { - Basic education } \\
\text { - Secondary } \\
\text { - University } \\
\end{array}$ & $\begin{array}{c}105 \\
61 \\
90 \\
126 \\
18\end{array}$ & $\begin{array}{c}26.25 \\
15.25 \\
22.5 \\
31.5 \\
4.5\end{array}$ \\
\hline $\begin{array}{l}\text { 4) Working status: } \\
\text { - Work } \\
\text { - Not-work }\end{array}$ & $\begin{array}{c}11 \\
389\end{array}$ & $\begin{array}{c}2.75 \\
97.25\end{array}$ \\
\hline 5) Body weight mean & \multicolumn{2}{|c|}{$72.5 \pm 12.35$} \\
\hline 6) Woman height mean: & \multicolumn{2}{|c|}{$157.9 \pm 11.84$} \\
\hline $\begin{array}{l}\text { 7) Body mass index (BMI): } \\
\text { - Under normal weight } \\
\text { - Normal weight } \\
\text { - Over normal weight } \\
\text { - Obese }\end{array}$ & $\begin{array}{c}1 \\
82 \\
191 \\
126\end{array}$ & $\begin{array}{c}0.25 \\
20.5 \\
47.75 \\
31.5\end{array}$ \\
\hline Total & 400 & 100.0 \\
\hline
\end{tabular}

Table (2): Distribution of studied women according to their obstetric history: $(n=400)$

\begin{tabular}{|c|c|c|}
\hline Obstetric history & n. (400) & $\%$ \\
\hline \begin{tabular}{|l|} 
1) Gravidity: \\
- Primigravida \\
- Multigravida \\
\end{tabular} & $\begin{array}{c}88 \\
312 \\
\end{array}$ & $\begin{array}{l}22.0 \\
78.0 \\
\end{array}$ \\
\hline $\begin{array}{l}\text { 2) Parity: } \\
\text { - Nullipara } \\
\text { - Primipara } \\
\text { - Multipara } \\
\end{array}$ & $\begin{array}{c}91 \\
11 \\
298 \\
\end{array}$ & $\begin{array}{l}22.75 \\
2.75 \\
74.5\end{array}$ \\
\hline \begin{tabular}{|l|} 
3) n. of live births \\
- No \\
- One \\
- More than one \\
\end{tabular} & $\begin{array}{r}97 \\
80 \\
223\end{array}$ & $\begin{array}{c}24.25 \\
20.0 \\
55.75\end{array}$ \\
\hline $\begin{array}{l}\text { 4) of abortions } \\
\text { - No } \\
\text { - One } \\
\text { - More than one } \\
\end{array}$ & $\begin{array}{l}320 \\
53 \\
27\end{array}$ & $\begin{array}{c}80.0 \\
13.25 \\
6.75\end{array}$ \\
\hline $\begin{array}{l}\text { 5) n. of still birth } \\
\text { - No } \\
\text { - One }\end{array}$ & $\begin{array}{c}388 \\
12\end{array}$ & $\begin{array}{c}97.0 \\
3.0\end{array}$ \\
\hline $\begin{array}{l}\text { 6) Mode of previous delivery } \\
\text { - Normal vaginal delivery } \\
\text { - Cesarean section }\end{array}$ & $\begin{array}{c}330 \\
70\end{array}$ & $\begin{array}{l}82.5 \\
17.5\end{array}$ \\
\hline $\begin{array}{l}\text { 7) Pervious pregnancy complications for mother } \\
\text { - None } \\
\text { - pre- eclampsia }\end{array}$ & $\begin{array}{c}307 \\
1\end{array}$ & $\begin{array}{c}76.75 \\
0.25\end{array}$ \\
\hline
\end{tabular}




\begin{tabular}{|l|c|c|}
\hline \multicolumn{1}{|c|}{ Obstetric history } & n. (400) & \% \\
\hline \hline • Abortion & 80 & 20.0 \\
- preterm labor & 8 & 2.0 \\
- postpartum hemorrhage & 1 & 0.25 \\
• Mix problems & 3 & 0.75 \\
\hline 8) Pervious complications for fetus or neonat: & 364 & \\
- None & 9 & 91.0 \\
- Premature birth & 22 & 2.25 \\
- Low birth weight & 5 & 5.5 \\
- Neonatal hypocalcaemia & $\mathbf{4 0 0}$ & 1.25 \\
\hline \multicolumn{1}{|c|}{ Total } & $\mathbf{1 0 0 . 0}$ \\
\hline
\end{tabular}

Table (3): Distribution of studied women according to their current obstetrical and medical data: $(n=400)$.

\begin{tabular}{|c|c|c|}
\hline Item & n. (400) & $\%$ \\
\hline $\begin{array}{l}\text { 1) Gestational age: } \\
\text { - Second trimester } \\
\text { - Third trimester }\end{array}$ & $\begin{array}{l}185 \\
215\end{array}$ & $\begin{array}{l}46.25 \\
53.75\end{array}$ \\
\hline $\begin{array}{l}\text { 2)Spacing between previous and current pregnancy: } \\
\text { - Less than one year } \\
\text { - From } 1-2 \text { years } \\
\text { - More than } 2 \text { years } \\
\text { - First pregnancy }\end{array}$ & $\begin{array}{l}5 \\
143 \\
164 \\
88\end{array}$ & $\begin{array}{c}1.25 \\
35.75 \\
41.0 \\
22.0\end{array}$ \\
\hline $\begin{array}{l}\text { 3) Current pregnancy complications: } \\
\text { - None } \\
\text { - Preeclampsia } \\
\text { - Gestational diabetes } \\
\text { - Genital infection } \\
\text { - Anemia }\end{array}$ & $\begin{array}{l}295 \\
9 \\
2 \\
25 \\
69\end{array}$ & $\begin{array}{c}73.75 \\
2.25 \\
0.5 \\
6.25 \\
17.25\end{array}$ \\
\hline $\begin{array}{l}\text { 4) Current medical disease: } \\
\text { - None } \\
\text { - Hypertension } \\
\text { - Anemia } \\
\text { - Hypocalcaemia } \\
\text { - Renal disease } \\
\text { - Cardiovascular diseases } \\
\text { - Musculoskeletal problem } \\
\text { - Others } \\
\end{array}$ & $\begin{array}{c}370 \\
8 \\
3 \\
4 \\
2 \\
1 \\
10 \\
2\end{array}$ & $\begin{array}{c}92.5 \\
2.0 \\
0.75 \\
1.0 \\
0.5 \\
0.25 \\
2.5 \\
0.5\end{array}$ \\
\hline Total & 400 & 100.0 \\
\hline
\end{tabular}

Others: (facial plasy and coagulopathy) 
Table (4): Distribution of studied women according to their current data of pregnant women related to vitamin $D$ deficiency: $(n=400)$.

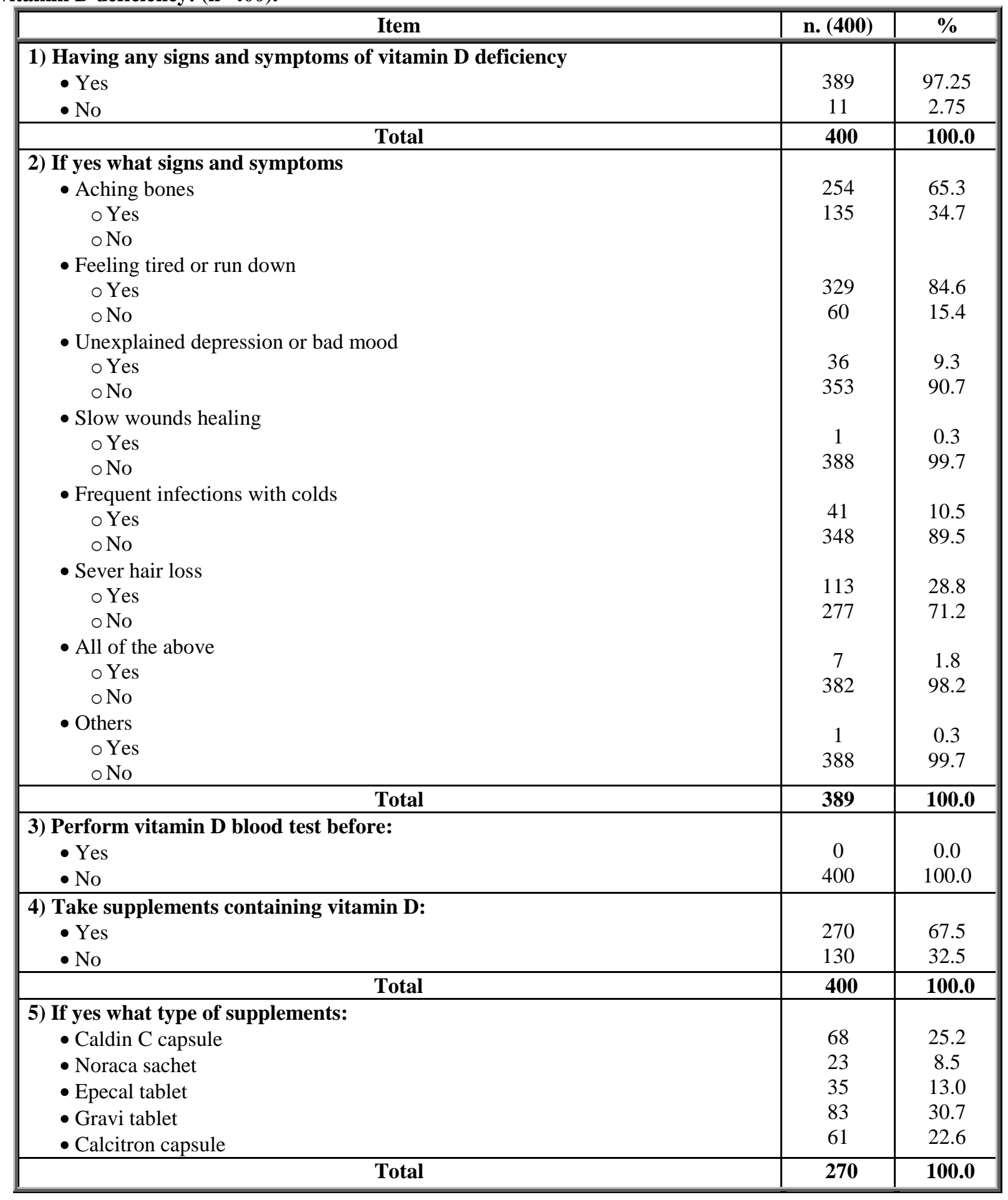




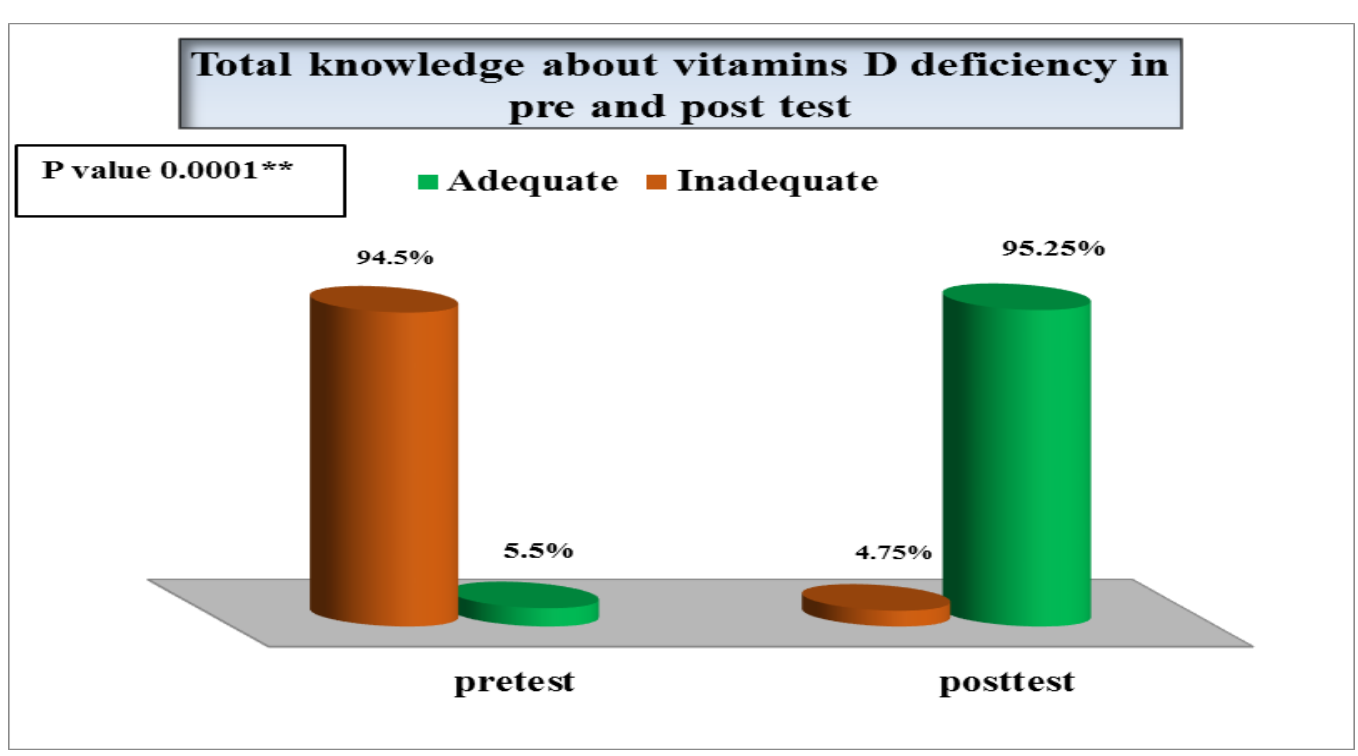

Figure (1): Distribution of studied women according to their total knowledge about vitamin D deficiency in pre and post test

Table (5): Relationship between sociodemographic characteristics and total knowledge in pre and posttest.

\begin{tabular}{|c|c|c|c|c|c|c|c|c|c|c|}
\hline \multirow{3}{*}{$\begin{array}{l}\text { Socio-demographic } \\
\text { characteristics }\end{array}$} & \multicolumn{4}{|c|}{ Total knowledge in pretest } & \multirow{3}{*}{ p-value } & \multicolumn{4}{|c|}{ Total knowledge in posttest } & \multirow{3}{*}{ p-value } \\
\hline & \multicolumn{2}{|c|}{ Adequate } & \multicolumn{2}{|c|}{ Inadequate } & & \multicolumn{2}{|c|}{ Adequate } & \multicolumn{2}{|c|}{ Inadequate } & \\
\hline & n. & $\%$ & n. & $\%$ & & n. & $\%$ & n. & $\%$ & \\
\hline $\begin{array}{l}\text { 1. Age/years: } \\
\text { - } 18-<25 \text { years } \\
\text { - } 26-<30 \text { years } \\
\text { - } 31-<35 \text { years } \\
\text { - }>35 \text { years }\end{array}$ & $\begin{array}{c}12 \\
6 \\
3 \\
1\end{array}$ & $\begin{array}{l}7.1 \\
4.4 \\
5.1 \\
2.7\end{array}$ & $\begin{array}{c}156 \\
130 \\
56 \\
36\end{array}$ & $\begin{array}{l}92.9 \\
95.6 \\
94.9 \\
97.3\end{array}$ & 0.624 & $\begin{array}{c}162 \\
129 \\
56 \\
34\end{array}$ & $\begin{array}{l}96.4 \\
94.9 \\
94.9 \\
91.9\end{array}$ & $\begin{array}{l}6 \\
7 \\
3 \\
3\end{array}$ & $\begin{array}{l}3.6 \\
5.1 \\
5.1 \\
8.1\end{array}$ & 0.682 \\
\hline $\begin{array}{l}\text { 2. Residence: } \\
\text { - Urban } \\
\text { - Rural }\end{array}$ & $\begin{array}{c}14 \\
8\end{array}$ & $\begin{array}{l}9.0 \\
3.3\end{array}$ & $\begin{array}{l}142 \\
236\end{array}$ & $\begin{array}{l}91.0 \\
96.7\end{array}$ & $0.015^{*}$ & $\begin{array}{l}156 \\
225\end{array}$ & $\begin{array}{c}100.0 \\
92.2\end{array}$ & $\begin{array}{c}0 \\
19\end{array}$ & $\begin{array}{l}0.0 \\
7.8\end{array}$ & $0.000 * *$ \\
\hline $\begin{array}{l}\text { 3. Educational level: } \\
\text { - Illiterate } \\
\text { - Read \&write } \\
\text { - Basic education } \\
\text { - Secondary } \\
\text { - University }\end{array}$ & $\begin{array}{l}2 \\
4 \\
2 \\
6 \\
8\end{array}$ & $\begin{array}{l}1.9 \\
6.6 \\
2.2 \\
4.8 \\
4.44\end{array}$ & $\begin{array}{c}103 \\
57 \\
88 \\
120 \\
10\end{array}$ & $\begin{array}{l}98.1 \\
93.4 \\
97.8 \\
95.2 \\
55.6\end{array}$ & $0.001 * *$ & $\begin{array}{c}98 \\
58 \\
85 \\
122 \\
18\end{array}$ & $\begin{array}{r}93.3 \\
95.1 \\
94.4 \\
96.8 \\
100.0\end{array}$ & $\begin{array}{l}7 \\
3 \\
5 \\
4 \\
0\end{array}$ & $\begin{array}{l}6.7 \\
4.9 \\
5.6 \\
3.2 \\
0.0\end{array}$ & 0.631 \\
\hline $\begin{array}{l}\text { 4. Working status: } \\
\text { - Work } \\
\text { - Not-work }\end{array}$ & $\begin{array}{c}6 \\
16\end{array}$ & $\begin{array}{c}54.5 \\
4.1\end{array}$ & $\begin{array}{c}5 \\
373\end{array}$ & $\begin{array}{l}45.5 \\
95.9\end{array}$ & $0.002 * *$ & $\begin{array}{c}11 \\
370\end{array}$ & $\begin{array}{c}100.0 \\
95.1\end{array}$ & $\begin{array}{c}0 \\
19\end{array}$ & $\begin{array}{l}0.0 \\
4.9\end{array}$ & 0.453 \\
\hline Total & 22 & 5.5 & 378 & 94.5 & $\begin{array}{l}400 \\
(100.0)\end{array}$ & 381 & 95.3 & 19 & 4.8 & $\begin{array}{c}400 \\
(100.0)\end{array}$ \\
\hline
\end{tabular}

(*) Statistically significant $p \leq 0.05$

(**) highly statistically significant $p \leq 0.01$ 
Table (6): Relationship between previous and current obstetric data and total knowledge in pre and posttest.

\begin{tabular}{|c|c|c|c|c|c|c|c|c|c|c|}
\hline \multirow{3}{*}{$\begin{array}{c}\text { Previous and current } \\
\text { obstetric data }\end{array}$} & \multicolumn{4}{|c|}{$\begin{array}{c}\text { Total knowledge in } \\
\text { pretest }\end{array}$} & \multirow{3}{*}{$\begin{array}{c}\text { p- } \\
\text { value }\end{array}$} & \multicolumn{4}{|c|}{ Total knowledge in posttest } & \multirow{3}{*}{ p-value } \\
\hline & \multicolumn{2}{|c|}{ Adequate } & \multicolumn{2}{|c|}{ Inadequate } & & \multicolumn{2}{|c|}{ Adequate } & \multicolumn{2}{|c|}{ Inadequate } & \\
\hline & n. & $\%$ & n. & $\%$ & & n. & $\%$ & n. & $\%$ & \\
\hline $\begin{array}{l}\text { 1) Gravidity } \\
\text { - Primigravida } \\
\text { - Multigravida }\end{array}$ & $\begin{array}{c}2 \\
20\end{array}$ & $\begin{array}{l}2.3 \\
6.4\end{array}$ & $\begin{array}{c}86 \\
292\end{array}$ & $\begin{array}{l}97.7 \\
93.6\end{array}$ & 0.133 & $\begin{array}{c}85 \\
296\end{array}$ & $\begin{array}{l}96.6 \\
94.9\end{array}$ & $\begin{array}{c}3 \\
16\end{array}$ & $\begin{array}{l}3.4 \\
5.1\end{array}$ & 0.503 \\
\hline $\begin{array}{l}\text { 2) Parity } \\
\text { - Non } \\
\text { - Primipara } \\
\text { - Multipara }\end{array}$ & $\begin{array}{c}2 \\
0 \\
20\end{array}$ & $\begin{array}{l}2.2 \\
0.0 \\
6.7\end{array}$ & $\begin{array}{c}89 \\
11 \\
278\end{array}$ & $\begin{array}{c}97.8 \\
100.0 \\
93.3\end{array}$ & 0.184 & $\begin{array}{c}87 \\
10 \\
284\end{array}$ & $\begin{array}{l}93.5 \\
90.9 \\
95.3\end{array}$ & $\begin{array}{c}4 \\
1 \\
14\end{array}$ & $\begin{array}{l}6.5 \\
9.1 \\
4.7\end{array}$ & 0.386 \\
\hline $\begin{array}{l}\text { 3) No of live births } \\
\text { - No } \\
\text { - One } \\
\text { - More than one }\end{array}$ & $\begin{array}{c}2 \\
6 \\
14\end{array}$ & $\begin{array}{l}2.1 \\
7.5 \\
6.3\end{array}$ & $\begin{array}{c}95 \\
74 \\
209\end{array}$ & $\begin{array}{l}97.9 \\
92.5 \\
93.7\end{array}$ & 0.241 & $\begin{array}{c}93 \\
77 \\
211\end{array}$ & $\begin{array}{l}95.9 \\
96.3 \\
94.6\end{array}$ & $\begin{array}{c}4 \\
3 \\
12\end{array}$ & $\begin{array}{l}4.1 \\
3.7 \\
5.4\end{array}$ & 0.809 \\
\hline $\begin{array}{l}\text { 4) No. of abortions } \\
\text { - No } \\
\text { - One } \\
\text { - More than one }\end{array}$ & $\begin{array}{l}19 \\
3 \\
0\end{array}$ & $\begin{array}{l}5.9 \\
5.7 \\
0.0\end{array}$ & $\begin{array}{c}301 \\
50 \\
27\end{array}$ & $\begin{array}{c}94.1 \\
94.3 \\
100.0\end{array}$ & 0.429 & $\begin{array}{c}309 \\
50 \\
22\end{array}$ & $\begin{array}{l}96.6 \\
94.3 \\
81.5\end{array}$ & $\begin{array}{l}11 \\
3 \\
5\end{array}$ & $\begin{array}{c}3.4 \\
5.7 \\
18.5\end{array}$ & $\begin{array}{c}0.002 \\
*\end{array}$ \\
\hline $\begin{array}{l}\text { 5) Mode of previous delivery } \\
\text { - Normal vaginal delivery } \\
\text { - Cesarean section }\end{array}$ & $\begin{array}{c}22 \\
0 \\
\end{array}$ & $\begin{array}{l}6.7 \\
0.0 \\
\end{array}$ & $\begin{array}{c}308 \\
70\end{array}$ & $\begin{array}{c}93.3 \\
100.0 \\
\end{array}$ & $0026 *$ & $\begin{array}{c}316 \\
65 \\
\end{array}$ & $\begin{array}{l}95.8 \\
92.9 \\
\end{array}$ & $\begin{array}{c}14 \\
5\end{array}$ & $\begin{array}{l}4.2 \\
7.1 \\
\end{array}$ & 0.789 \\
\hline $\begin{array}{l}\text { 6) Gestational age: } \\
\text { - Second trimester } \\
\text { - Third trimester }\end{array}$ & $\begin{array}{c}6 \\
16\end{array}$ & $\begin{array}{l}3.2 \\
7.4\end{array}$ & $\begin{array}{l}179 \\
199\end{array}$ & $\begin{array}{l}96.8 \\
92.6\end{array}$ & 0.066 & $\begin{array}{l}178 \\
203\end{array}$ & $\begin{array}{l}96.2 \\
94.4\end{array}$ & $\begin{array}{c}7 \\
12\end{array}$ & $\begin{array}{l}3.8 \\
5.6\end{array}$ & 0.399 \\
\hline $\begin{array}{l}\text { 7) Spacing between previous } \\
\text { \& current pregnancy } \\
\text { - First pregnancy } \\
\text { - < one year } \\
\text { - From } 1-2 \text { years } \\
\text { - > } 2 \text { years }\end{array}$ & $\begin{array}{c}1 \\
1 \\
13 \\
7\end{array}$ & $\begin{array}{c}1.1 \\
20 . \\
0 \\
9.1 \\
4.3\end{array}$ & $\begin{array}{c}87 \\
4 \\
130 \\
157\end{array}$ & $\begin{array}{l}98.9 \\
80.0 \\
90.9 \\
95.7\end{array}$ & 0.101 & $\begin{array}{c}86 \\
3 \\
136 \\
156\end{array}$ & $\begin{array}{l}97.7 \\
60.0 \\
95.1 \\
95.1\end{array}$ & $\begin{array}{l}2 \\
2 \\
7 \\
8\end{array}$ & $\begin{array}{c}2.3 \\
40.0 \\
4.9 \\
4.9\end{array}$ & 0.215 \\
\hline Total & 22 & 5.5 & 378 & 94.5 & $\begin{array}{c}400 \\
(100.0)\end{array}$ & 381 & 95.3 & 19 & 4.8 & $\begin{array}{c}400 \\
(100.0)\end{array}$ \\
\hline
\end{tabular}

(*) Statistically significant $p \leq 0.05$

Table (7): Relationship between current vitamin D data and total knowledge in pre and posttest.

\begin{tabular}{|c|c|c|c|c|c|c|c|c|c|c|}
\hline \multirow{3}{*}{ Current vitamin D data } & \multicolumn{4}{|c|}{$\begin{array}{c}\text { Total knowledge in } \\
\text { pretest }\end{array}$} & \multirow{3}{*}{$\begin{array}{c}\text { p- } \\
\text { value }\end{array}$} & \multicolumn{4}{|c|}{$\begin{array}{c}\text { Total knowledge in } \\
\text { posttest }\end{array}$} & \multirow{3}{*}{ p-value } \\
\hline & \multicolumn{2}{|c|}{ Adequate } & \multicolumn{2}{|c|}{ Inadequate } & & \multicolumn{2}{|c|}{ Adequate } & \multicolumn{2}{|c|}{ Inadequate } & \\
\hline & n. & $\%$ & n. & $\%$ & & n. & $\%$ & n. & $\%$ & \\
\hline $\begin{array}{l}\text { 1. Having any signs and } \\
\text { symptoms of vitamin } \\
\text { D deficiency: } \\
\text { - Yes } \\
-\quad \text { No }\end{array}$ & $\begin{array}{c}22 \\
0\end{array}$ & $\begin{array}{l}5.7 \\
0.0\end{array}$ & $\begin{array}{c}367 \\
11\end{array}$ & $\begin{array}{c}94.3 \\
100.0\end{array}$ & 0.417 & $\begin{array}{c}379 \\
2\end{array}$ & $\begin{array}{l}97.4 \\
18.2\end{array}$ & $\begin{array}{r}10 \\
9\end{array}$ & $\begin{array}{c}2.6 \\
81.8\end{array}$ & $\underset{*}{\mathbf{0 . 0 0 1}} *$ \\
\hline $\begin{array}{l}\text { 2. Take supplements } \\
\text { containing vitamin D: } \\
\text { - Yes } \\
\text { - No }\end{array}$ & $\begin{array}{c}19 \\
3\end{array}$ & $\begin{array}{l}7.0 \\
2.3\end{array}$ & $\begin{array}{l}251 \\
127\end{array}$ & $\begin{array}{l}93.0 \\
97.7\end{array}$ & $0.052 *$ & $\begin{array}{l}259 \\
122\end{array}$ & $\begin{array}{l}95.9 \\
93.8\end{array}$ & $\begin{array}{c}11 \\
8\end{array}$ & $\begin{array}{l}4.1 \\
6.2\end{array}$ & 0.4514 \\
\hline Total & 22 & 5.5 & 378 & 94.5 & $\begin{array}{c}400 \\
(100.0)\end{array}$ & 381 & 95.3 & 19 & 4.8 & $\begin{array}{c}400 \\
(100.0)\end{array}$ \\
\hline
\end{tabular}

(*) Statistically significant $p \leq 0.05$

(**) highly statistically significant $p \leq 0.01$ 
Table (1): Regarding demographic characteristics of the studied pregnant women show that the majority of them $(76 \%)$ were under 30 years old, their mean age was $27.3 \pm 5.48$, more than half rural and almost all not working, their body weight mean (72.5 \pm 12.35 ), around half of them over normal weight and $31.5 \%$ are obese.

Table (2): Show that the majority of studied pregnant women was Multigravida and multipara, some of them have one abortion $(13.25 \%)$ and less have more than one abortion $(6.75 \%)$, just few of them had astill birth and most of them delivered with normal vaginal delivery mode.

Table (3): Show that more than half of the studied pregnant women $(53.75 \%)$ were in third trimester, few of them had preeclampsia and genital infections, and around one-fifth of them $(17.25 \%)$ was anemic.

Table (4): Show that almost all of the studied women $(97.25 \%)$ have signs and symptoms of vitamin D deficiency, none of them perform vitamin $\mathrm{D}$ blood test before and more than half of them $(67.5 \%)$ take supplements containing vitamin D as doctor prescription.

Figure (1): Demonstrate that almost all of studied women have adequate $(95.25 \%)$ toward total knowledge about vitamin D in post counseling, although most of them were inadequate in pre counseling $(94.5 \%)$ with statistically significant $\mathrm{p} \leq$ 0.0001 .

Table (5): Described that the highest percentage association between the studied women socio demographic characteristics and their total knowledge about vitamin D after counseling in young age $(96.4 \%)$, urban $(100 \%)$, university education $(100 \%)$ and working (100\%) with statistically significant $\mathrm{p} \leq 0.05$.

Table (6): Show that there was statistically significant difference between women' knowledge and their previous and current obstetric data in prepost counseling.

Table (7): Show that almost all of the studied pregnant women have adequate $(95.3 \%)$ toward total knowledge about vitamin D in post counseling, although most of them were inadequate in pre counseling $(94.5 \%)$ with statistically significant $\mathrm{p} \leq$ 0.05 .

\section{Discussion}

Vitamin D deficiency is considered to be common among pregnant women in some populations, and has been found to be associated with an increased risk of pre-eclampsia, gestational diabetes mellitus, preterm birth, and other tissue-specific conditions (WHO, 2019). Maternal vitamin D insufficiency during pregnancy is a common issue and a significant public health problem at the global level (Larqu et al., 2018).

Vitamin D deficiency is reportedly common worldwide and has been linked to an increased risk of a wide range of diseases. There has been a tendency to recommend high blood levels of vitamin D for optimum health (Lucas, 2015), the prevalence of vitamin $\mathrm{D}$ deficiency has increased and continues to be a broad public health problem in many countries. High prevalence of vitamin D deficiency has been observed among pregnant women even in sun-rich areas (Ates, 2016).

Therefore, the aim of this study was to evaluate the effect of counseling on vitamin D deficiency among pregnant women in Abo-teg health center. Regarding socio-demographic data, the present study revealed that the majority of studied women were under thirty years old, these findings supported by Prasad et al., (2018) who found in their study about vitamin D in pregnancy and its correlation with feto maternal outcome that more than half of the patients were > thirty years old.

As well, the study by Hong-Bi et al., (2018) which entitled "High prevalence of vitamin D deficiency in pregnant women and its relationship with adverse pregnancy outcomes in Guizhou, China" who found that the majority of the pregnant women that enrolled in their study were twenty two to thirty four years old.

While the current study finding was not in the same line with the study about measurement of Serum Vitamin D25 Level in Normal Egyptian Population by Mousa et al., (2018) who revealed that total of ninety healthy individuals, half of them were males their age ranged from twenty to fifty nine years old and the other half females with age range between eighteen to fifty eight years old.

The present study result was congruent with a study conducted by Woon et al., (2019) who found in their study which entitled "Vitamin D deficiency during pregnancy and its associated factors among third trimester Malaysian pregnant women" of 535 pregnant women, that more than half of them were multigravida and the majority of them take of supplements containing vitamin D.

Based on this study result vast majority of the studied pregnant women had signs and symptoms of vitamin D deficiency. The study findings were in line with study entitled High prevalence of severe vitamin D deficiency in Egyptian females" by Botros et al., (2019) as they found that around onethird of the subjects had severe vitamin D deficiency and about one-fifth of all the subjects studied had Vitamin D>30 ng/ml.

Also this finding sported by the results of the study done by Osman et al., (2020) which entitled " 
Prevalence of vitamin D deficiency in Egyptian patients with pregnancy-induced hypertension" reported that level of $25(\mathrm{OH}) \mathrm{D}$ was lower in the preeclampsia and in the eclampsia group than in the pregnant controls with. Deficiency of vitamin D was about fifty percentage in the pre-eclampsia group, eighty percentage in the eclampsia group and only ten percentage in the control group.

As well, the study done by Massoud et al., (2018) entitled "Vitamin D status in a neonate-mother pair attending Alexandria University Children's Hospital during the first week of life" was recorded statistically significant relation between the mothers serum vitamin $\mathrm{D}$ status and their newborn, with a positive correlation between vitamin D levels in the serum of both, insufficient calcium supplementation during the second and third trimester of pregnancy, inadequate sunlight exposure, frequent previous pregnancies, and low levels of 1, 25dihydroxyvitamin D.

Generally, the current study demonstrated that almost all of the studied pregnant women had adequate toward total knowledge about vitamin $\mathrm{D}$ in post counseling with statistically significant, and they know the effect of vitamin D deficiency on mother and fetus. From researcher's point of view, this will increase the eagerness of pregnant women to obtain vitamin $\mathrm{D}$ from its natural sources to improve their health and the health of their children. and this clarified the importance of counseling on vitamin $\mathrm{D}$.

\section{Conclusion}

Based on the present study results, it can be concluded that, counseling on vitamin D deficiency and its effect on pregnancy outcomes is effective and elevated the pregnant women`s knowledge towards vitamin $\mathrm{D}$ and this will enhance pregnant women health and their babies.

\section{Recommendations}

Based on the present study findings, the following recommendations were derived:

- Counseling on vitamin D and its deficiency effect on pregnant women`s health should be circulated in all maternal and child health centers through holding informative seminars for pregnant women about vitamin $\mathrm{D}$ and its importance for mothers and their children. Giving them illustrated brochures to attract their attention and making simple educational posters that attached to all maternal and child health centers. This would improve women's knowledge on vitamin $\mathrm{D}$ and decrease the incidence of vitamin $\mathrm{D}$ deficiency complications.
- More researches are needed to investigate the effectiveness of counseling on vitamin D. Further studies on large sample from different geographic areas in Egypt to generalize the results.

\section{References}

- Ates, S., Sevket, O., Ozcan, P., Ozkal, F., Kaya, M., \& Dane, B., (2016): Vitamin D status in the first-trimester: effects of Vitamin D deficiency on pregnancy outcomes, African Health Sciences http://dx.doi.org/10.4314/ahs.v16i1.5

- Botros, R., Al Sebaeiy, H., Mansour, H., \& Guirgis, M., (2019): High prevalence of severe vitamin D deficiency in Egyptian females, Endocrine Abstracts 63 P473 | DOI: 10.1530/endoabs.63.P473

- Debra, R,. (2020): The Benefits of Vitamin D available at: https://www.healhline.com

- Fogacci, S., Fogacci, F., Banach, M., Michos, E., Hernandez, A., Blaha, M., Toth, P., Borghi, C., \& Cicero, A., (2019): Vitamin D supplementation and incident preeclampsia: A systematic review and meta-analysis of randomized clinical trials, Clinical Nutrition, https://doi.org/10.1016/j.clnu.2019.08.015

- Ganguly, A., Tamblyn, J., Finn-Sell, S., Chan, S., Westwood, M., Gupta, J., Kilby, M., Gross, S., \& Hewison, M., (2018): Vitamin D, the placenta and early pregnancy: effects on trophoblast function, Journal of Endocrinology, available at: m.hewison@bham.ac.uk https://doi.org/10.1530/JOE-17-0491 http://joe.endocrinology-journals.org

- Hong-Bi, S., Yin, X., Xiaowu, Y., Ying, W., Yang, X., Ting, C., \& Na, W., (2018): High prevalence of vitamin D deficiency in pregnant women and its relationship with adverse pregnancy outcomes, Journal of International Medical Research

http://www.creativecommons.org/licenses/bync/4.0/

- Larqu, E., Morales, E., Leis, R., \& Carnero, J., (2018): Maternal and Foetal Health Implications of Vitamin D Status during Pregnancy, https://doi.org/10.1159/000487370

- Lucas, R., (2015): Vitamin D deficiency, nursing in practice. https://www.nursinginpractice.com/

- Massoud, M., Rizk, M., Mahfouz, A., \& Mahmoud, N., (2018): Vitamin D status in a neonate-mother pair attending Alexandria University Children's Hospital during the first week of life. Alex J Pediatr [serial online] 2018 [cited 2020 Nov 22]; 31:52-8. Available from: http://www.ajp.eg.net/text.asp?2018/31/2/52/ 247304 
- Mohamed, N., Mohamed, M., Mahfouz, M., \& Mahmoud, A., (2019): Vitamin D status in a neonate-mother pair attending Alexandria University Children's Hospital during the first week of life. Available at http://www.ajp.eg.net on Saturday, October 26, , IP: 197.36.178.91

- Mousa, S., Ismail, S., Mohamed, N., \& Abd Allah, O., (2018): Measurement of Serum Vitamin D25 Level in Normal Egyptian Population, AlAzhar University, Cairo, Egypt. Clinical Medicine and http://creativecommons.org/licenses/by/4.0/

- National Institutes of Health (2016): Vitamin D Fact Sheet for Consumers Available at: http://ods.od.nih.gov or e-mail us at ods@nih.gov

- National Institutes of Health (2020): Vitamin D Health Professional Fact Sheet.mhtml

- Osman, M., Gaafar, T., Eissa, T., Abdella, R., Ebrashy, A., \& Ellithy, A., (2020): Prevalence of vitamin D deficiency in Egyptian patients with pregnancy-induced hypertension, Journal of Perinatal

Medicine DOI: https://doi.org/10.1515/jpm-20200055

- Prasad, D., Singh, K., \& Nisha, S., (2018): Vitamin D in pregnancy and its correlation with feto maternal outcome. International Journal of Contemporary Medical Research

- Raif, M., Sabry, M., Abdelbaky, S., Eid, M., Nasr, S., \& Hendawy, M., (2015): Vitamin D deficiency among healthy Egyptian females, Ain Shams, Egypt. available at : http://www.elsevier.es/

- Siemens Healthineers (2019): Vitamin D available at: https://www.siemenshealthineers.com/en-usa/bone-metabolism/fag-cdcvitamin-d

- Woon, F., Chin, Y., Ismail, I., Batterham, M., Abdul Latiff, A., \& Gan, W., (2019): Vitamin D deficiency during pregnancy and its associated factors among third trimester Malaysian pregnant women, PLoS ONE 14(6): e0216439. https://doi.org/10.1371/journal.pone.0216439

- World Health Organization (2019): Vitamin D supplementation during pregnancy, available at: http://who.net/ Vitamin D supplementation during pregnancy 